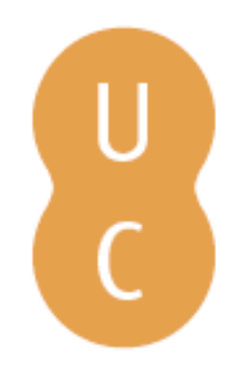

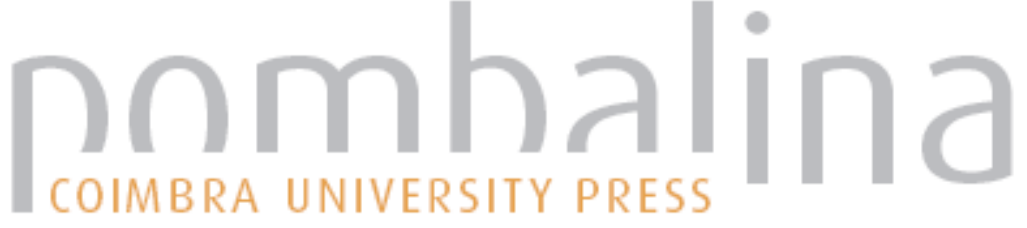

\section{A universal rate of spread index for Australian fuel types}

Autor(es): $\quad$ Sharples, Jason J.; Bahri, Mona F. Z.; Huntley, Steve

Publicado por: Imprensa da Universidade de Coimbra

URL

persistente: URI:http://hdl.handle.net/10316.2/44649

DOI: $\quad$ DOI:https://doi.org/10.14195/978-989-26-16-506_132

Accessed : $\quad$ 26-Apr-2023 13:18:20

A navegação consulta e descarregamento dos títulos inseridos nas Bibliotecas Digitais UC Digitalis, UC Pombalina e UC Impactum, pressupõem a aceitação plena e sem reservas dos Termos e Condições de Uso destas Bibliotecas Digitais, disponíveis em https://digitalis.uc.pt/pt-pt/termos.

Conforme exposto nos referidos Termos e Condições de Uso, o descarregamento de títulos de acesso restrito requer uma licença válida de autorização devendo o utilizador aceder ao(s) documento(s) a partir de um endereço de IP da instituição detentora da supramencionada licença.

Ao utilizador é apenas permitido o descarregamento para uso pessoal, pelo que o emprego do(s) título(s) descarregado(s) para outro fim, designadamente comercial, carece de autorização do respetivo autor ou editor da obra.

Na medida em que todas as obras da UC Digitalis se encontram protegidas pelo Código do Direito de Autor e Direitos Conexos e demais legislação aplicável, toda a cópia, parcial ou total, deste documento, nos casos em que é legalmente admitida, deverá conter ou fazer-se acompanhar por este aviso. 


\section{ADVANCES IN}

\section{FOREST FIRE RESEARCH}

\section{8}

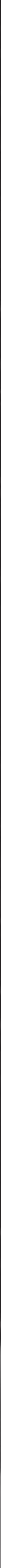


Short contribution - Fire Risk Management

\title{
A universal rate of spread index for Australian fuel types
}

\author{
Jason J. Sharples ${ }^{1 *}$; Mona F. Z. Bahri²; Steve Huntley ${ }^{3,4}$ \\ ${ }^{I}$ School of Physical, Environmental and Mathematical Sciences, UNSW Australia, \\ \{j.sharples@adfa.edu.au*\} \\ ${ }^{2}$ School of Physical, Environmental and Mathematical Sciences, UNSW Australia, \\ ${ }^{3}$ NSW National Parks and Wildlife Service, Office of Environment \& Heritage \\ ${ }^{4}$ Charles Sturt University
}

\begin{abstract}
Empirical fire spread models for Australian fuel types date back to the 1950s-60s, with the work of Alan McArthur, and extend through to the current day with the most recent developments in shrubland fire spread models and refinements to the curing function in grassland fire spread models. These models are designed to provide a relatively simple and timely answer to the question: "Given a specific set of environmental conditions, what is the expected forward rate of spread of a fire?" In this paper we present a critical analysis of the the current suite of fire spread models employed operationally in Australia. In particular, we explore the functional form and parametric dependence of these rate of spread models. We then introduce an alternative functional form for predicting rate of spread, which is remarkable parsimonious compared to current operational models. We further show that this single functional model can be used as a universal index for fire spread, by which we mean that the same model can be applied to different fuel types and produce numerical predictions that are practically identical to those produced by the existing suite of operational models used in Australia.
\end{abstract}

Keywords: Rate of spread, eucalypt, grassland, shrubland, model parsimony, wind, fuel moisture content

\section{Introduction}

One of the main goals of wildfire research is to provide a relatively simple and timely answer to the question: "Given a specific set of environmental conditions, what is the expected forward rate of spread of a fire?" Indeed, pursuit of such an answer has engaged some of the brightest minds in wildland fire science, and has produced a variety of fire spread models that apply across a number of common vegetation or fuel types. In Australia, these models date back to the 1950s-60s, with the work of Alan McArthur, and extend through to the current day with the most recent developments in shrubland fire spread models and refinements to the curing function in the CSIRO grassland fire spread model. In this paper we show how consider the way that meteorological factors are incorporated into the suite of existing fire spread models, which encompass a variety of different fuel types, and discuss an approach that unifies their inclusion. The utility of this unified modelling approach is demonstrated via model comparison using real meteorological data over a range of vegetation types. In particular, we demonstrate that the meteorological (i.e. non-fuel) sub-models of the current suite of operational models, which are of many and varied functional form, can be replaced by a single, unified, twoparameter model, with no appreciable loss in model performance. The unified model has the distinct advantage of being conceptually straightforward and extremely parsimonious compared to current operational approaches. The existence of a simple, yet effective, unified approach to fire spread modelling has implications for initiatives such as the National Fire Danger Rating project, as it establishes a common modelling basis that can be applied to the many different fuel types that are encountered across the nation. 


\section{Rate of fire spread models for Australian fuel types}

We consider current operational models for the following fuel types: grasslands; buttongrass moorland; temperate shrubland; South Australian mallee-heath; and dry eucalypt forest. The rate of spread models for each of these fuel types are described in detail by Cruz et al. (2015).

In this study we specifically focus on how the rates of spread derived from the models mentioned above depend on the fire weather variables: temperature, relative humidity and wind speed. Fuelrelated factors such as availability and structural descriptors (e.g. fuel height) are assumed constant for each fuel type.

It is of interest to note the number of model parameters that are associated with each of the rate of spread models for the different fuel types considered. These parameters represent degrees of freedom in the model, and have to be determined through regression-type analyses of empirical data relating to the rate of spread and environmental predictor variables. Ignoring their fuel dependent components, the grassland model has 10 parameters (Cheney et al., 1998), the buttongrass moorland model has 6 parameters (Marsden-Smedley and Catchpole, 1995), the temperate shrubland model has 9 parameters (Anderson et al., 2015), the S.A. mallee-heath model has 7 parameters (Cruz et al., 2010), and the dry eucalypt forest model has 13 parameters (Cheney et al., 2012).

\section{Universal rate of spread index}

Previous work (e.g. Sharples and McRae, 2012) has considered the utility of the following simple dimensionless index in describing fuel moisture content. The fuel moisture index is defined as:

$$
F M I=10-0.25(T-H),
$$

where $T$ is air temperature $\left({ }^{\circ} \mathrm{C}\right)$ and $H$ is relative humidity $(\%)$.

The FMI has been combined with wind speed in simple functional forms, which have been shown to provide estimates of fire danger and rates of spread that are comparable to those derived from accepted models. In this work, we extend this idea, and examine how predictions from a simple, twoparameter model for fire spread, based on wind speed $U$ and $F M I$, compares to those from the various models for different fuel types. The particular model, which we refer to as the spread index, is:

$$
S(\mu, p)=\left(\frac{\max (1, U)}{F M I+\mu}\right)^{p}
$$

where $\mu$ and $p$ are the two parameters defining the model.

To facilitate the comparison between current operational models and the spread index, we use halfhourly fire weather data recorded at Canberra Airport between November 2006 - March 2007; that is, approximately over the course of a fire season.

\section{Results}

In this preliminary work the spread index parameters $\mu$ and $p$ were varied by hand until a good fit was obtained between predictions of the spread index and those arising from each of the rate of spread models for grassland, buttongrass, temperate shrubland, S.A. mallee-heath and dry eucalypt forest. An example of a comparison of the predictions of the spread index compared to the predictions of the temperate shrubland model (Anderson et al., 2015) and the dry eucalypt model (Cheney et al., 2012) can be seen in Figure 1. Note that in each case the spread index values have been scaled so that their mean equals the mean of the predictions from the fuel-specific model. 
In the worst case the spread index accounts for around $94 \%$ of the variability in the dry eucalypt forest rate of spread model, while in the best case it accounts for over $99 \%$ of the variability in buttongrass moorland model.
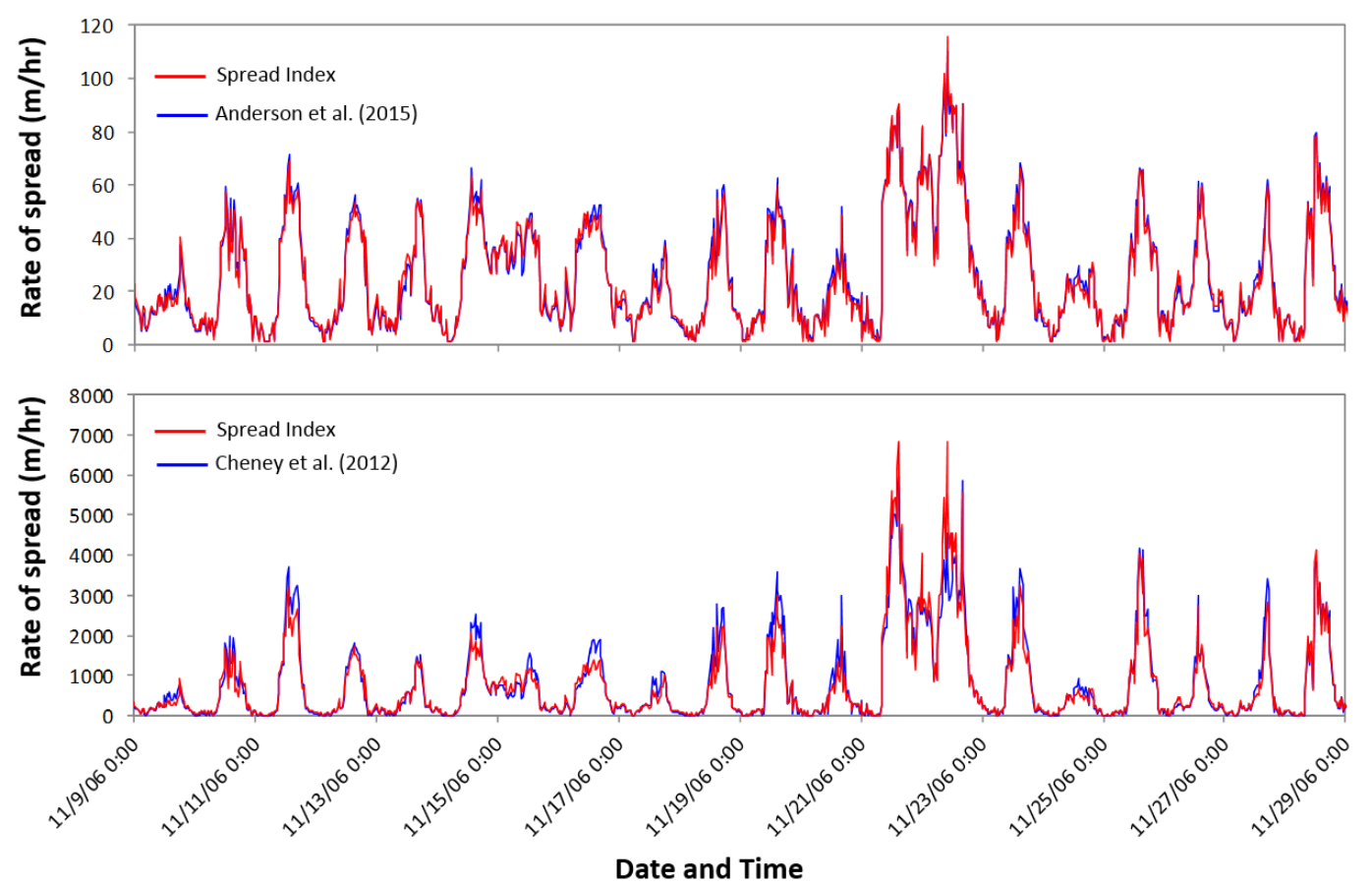

Figure 1 - Rate of spread predictions from the temperate shrubland model of Anderson et al. (2015) and the dry eucalypt forest fire model of Cheney et al. (2012) compared to those from the spread index. The spread index values have been scaled in each case so that their mean value matches the mean value of the fuel-specific model predictions.

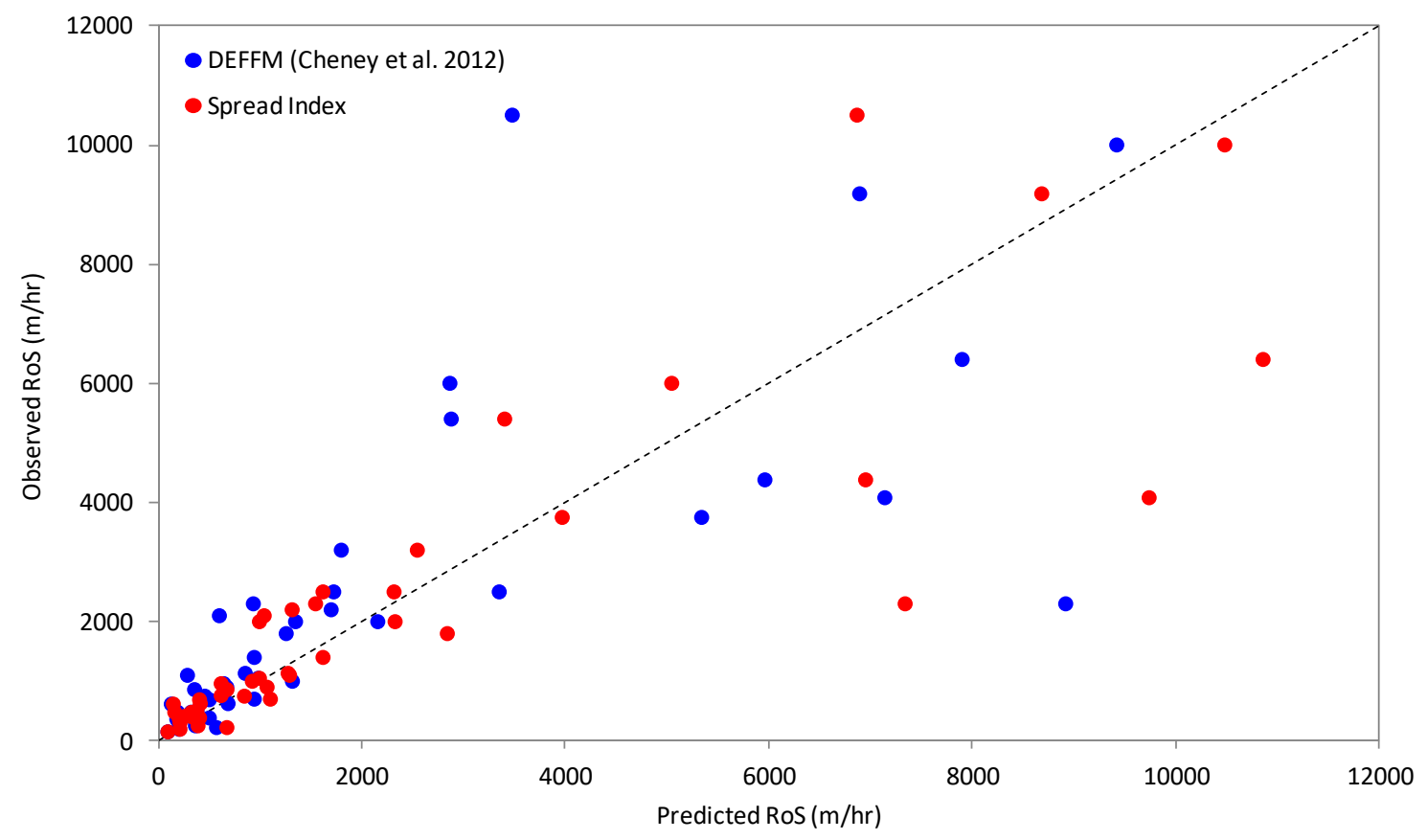

Figure 2 - Observed wildfire rates of spread plotted against predictions from the dry eucalypt forest fire model (DEFFM) of Cheney et al. (2012) and the spread index. The same scaling as utilised in Figure 1 (bottom panel) has again been applied to the spread index. 
The spread index also produces results that are comparable to existing operational models when used to predict wildfire observations. Figure 2 shows observed wildfire rates of spread plotted against predictions made using the dry eucalypt forest fire model of Cheney et al. (2012) (blue dots) and those made using the spread index (red dots). Note that the same scaling has been applied to the raw spread index values as was applied to obtain the values shown in the bottom panel of Figure 1. Overall statistics indicated that the model of Cheney et al. (2012) gave rate of spread predictions with a mean absolute error of $51 \%$ and a mean bias error of $-24 \%$, while the simple spread index gave rate of spread predictions with a mean absolute error of $44 \%$ and a mean bias error of $-24 \%$. These results suggest that the spread index provides the better guidance on assessing wildfire rate of spread. In particular, these statistics indicate that spread index offers a three-fold improvement over the model of Cheney et al. (2012) in under-predicting actual rates of spread. This result is even more remarkable when we note that no information on fuel was included in the spread index calculations, while the predictions of the model of Cheney et al. (2012) utilized detailed information on fuel via surface and near-surface fuel hazard scores and near-surface fuel height.

\section{Conclusions}

Predictions from the meteorological sub-models of five state-of-the-art fire spread models were compared with predictions derived from a single two-parameter fire spread index. The results indicated that the simple spread index was able to reproduce the predictions of the more complicated models to a remarkable degree of accuracy $\left(R^{2}=0.94-0.99\right)$. The results further suggest that the state-of-the-art models are considerably over-complicated: the predictions from models with 6-13 parameters can all be accurately emulated by a model with only two parameters (or three parameters, if a scaling/calibration factor is included). This indicates that the current suite of operational models have about 2-6 times more free parameters than necessary. Indeed, the spread index offers a far more parsimonious approach to modelling rate of spread, is far more conceptually simple, and provides a unified way of assessing rate of spread across a variety of fuel types.

\section{References:}

Anderson WR, Cruz MG, Fernandes PM, McCaw L, Vega JA, Bradstock RA, Fogarty L, Gould J, McCarthy G, Marsden-Smedley JB, Matthews S. A generic, empirical-based model for predicting rate of fire spread in shrublands. International Journal of Wildland Fire 2015; 24: 443-460.

Cheney NP, Gould JS, Catchpole WR. Prediction of fire spread in grasslands. International Journal of Wildland Fire 1998; 8: 1-3.

Cheney NP, Gould JS, McCaw WL, Anderson WR. Predicting fire behaviour in dry eucalypt forest in southern Australia. Forest Ecology and Management 2012; 280: 120-131.

Cruz MG, Matthews S, Gould J, Ellis P, Henderson M, Knight I, Watters J. Fire dynamics in malleeheath: fuel, weather and fire behaviour prediction in south Australian semi-arid shrublands. Bushfire Cooperative Research Centre, Report A; 2010.

Cruz MG, Gould JS, Alexander ME, Sullivan AL, McCaw WL, Matthews S. A Guide to Rate of Fire Spread Models for Australian Vegetation. CSIRO Land and Water Flagship and AFAC: Canberra, ACT and Melbourne, VIC; 2015.

Marsden-Smedley JB, Catchpole WR. Fire behaviour modelling in Tasmanian buttongrass moorlands. II. Fire behaviour. International Journal of Wildland Fire 1995; 5: 215-228.

1Sharples JJ, McRae RH. Evaluation of a very simple model for predicting the moisture content of eucalypt litter. International Journal of Wildland Fire 2012; 20:1000-1005. 